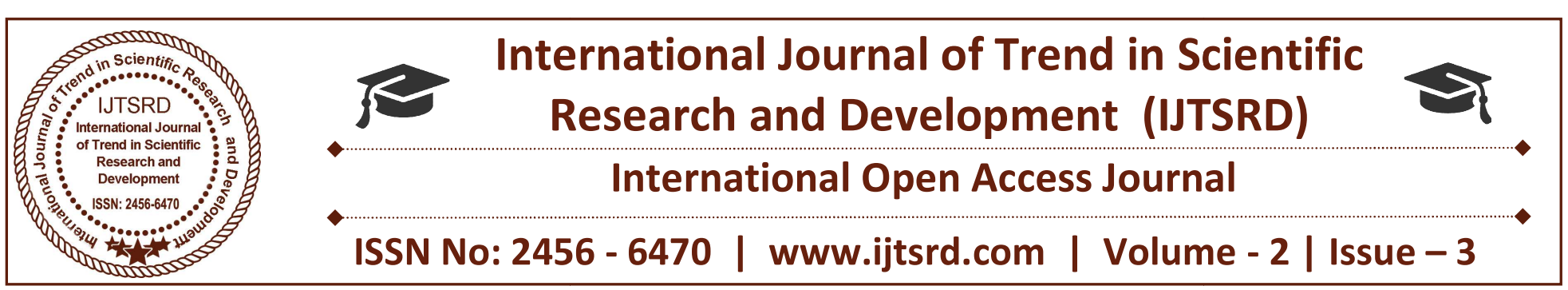

\title{
Working Conditions and Issues of Women Workers in an Unorganized Sector - Special Reference to Construction Sector of Thuraiyur Taluk, Tiruchirappalli
}

\author{
${ }^{1}$ S. Rasheedha Banu \\ Doctoral Scholar, Department of Sociology, \\ Bharathidasan University, Trichirappalli, India
}

\author{
${ }^{2}$ Dr. S.Sampath Kumar \\ Professor and Head, Department of Sociology, \\ Bharathiyar University, Coimbatore, India
}

\section{ABSTRACT}

Construction industry is one of the unorganized sector, which employing a large number of people on its work force. A wide range of activities are involved in it. About one third of these workforce employed in this industry are women workers have to face several difficulties at the work place. The pathetic conditions are that women workers in this industry are almost unskilled labourers. Researcher adopted Descriptive Research Design and Data collected from 63 women workers in Thuraiyur Taluk.Tiruchirappalli District, Tamil Nadu. The researcher has selected the simple Random sampling from probability sample Design and the data for this study has been collected through primary source. The primary data for this study was collected with the help of the semi structured interview schedule. This paper attempts to analyse the working conditions, wage discrimination, exploitation, harassment and problems of women workers in construction industry in the study area.

Keywords: Working Conditions and Problems, women workers, Unorganized Sector

\section{INTRODUCTION}

The Construction industry place very important role in the socio-economic of the country. It is closely associated with nation's economy. India is the one of the fastest growing economies in of the world. Construction sector is providing employment to seven percent of total world employment. In India, it is the largest employer of unorganized labor next to Agriculture sector. The construction industry provides job opportunity to large number of skilled as well as un-skilled work force. Construction workers are the back bone of the economy as they create the infrastructure necessary for industrial growth. In a globalization economy, it is they who are constructing the new economy. These construction workers are from poor families and are illiterates. Their lack of education and skill make their choice very limited. They have to face number of problems because of their inexperience and lack of skill. They become easy victim of exploitation and gender discrimination for work allocation and wage distribution. Sexual harassment is a serious problem for women construction workers. They faced different health hazards, physical problems and adverse out comes.

\section{Women in an unorganized sector}

The term unorganized sector was first used by Hart in 1971 who described the unorganized sector as that part of urban labour force, which falls outside the organized labour market. In the unorganized sector, work situations are not in official record and working conditions are not protected by law. Moreover the problems of female workers in unorganized sector are not properly known. It has been pointed out by Hart that one of the major problems is that working conditions are worst due to population growth and urban migration, the active labour force was growing at a much faster rate than availability of jobs in the organized sector. The focus of development policies was gradually shifting from pure economic to growth based with equity and the eradication of poverty. Interest was, thus generated in sectors outside the 
organized economy that was providing a livelihood to a large section of the poor. Hence, the concept of the unorganized sector was born. In defining the unorganized sector, self- employed with or without family labour and microenterprises with less than five workers, is also included.

\section{Construction women workers}

Women play a prominent role at various levels in our economic status. They are the backbone of our nation. Both men and women are integral part of the society. Give appropriate skills and opportunities of decision making, women can prove that they are not less than men. The women employment in the construction industry is very high, even though they work only as the helpers or unskilled workers. Their skills are always at the same level and are not upgraded as they assist only the male work force at the work place. About one third of these workers are women and children. Construction workers as a whole are included in exploited category of workers. Women workers within this category are subject to a more intensive from the job insecurity.

\section{Working Conditions of the Women Workers}

Women occupy an extremely disadvantages position in the society. They are the victims of multiple forms of oppression. This is because they are women and they are occupied in mostly exploited areas in the society. Despite the existence of various constitutional and legal provisions guarding women in an employment, particularly in the unorganized sector; suffer from various disadvantages relating to their working lives as well as their home.

Rajanna (2015) conducted a study on Socioeconomic status of women worker in Chikmagalur District of Karnataka, A sample of 300 women construction workers in Chikmagalur district were selected for this study of this sector was very important to get an insight of the existing Socio-economic conditions of women construction workers in this district. The paper recommends certain policies for the Socioeconomic upliftment of the women construction workers.

Subramani, et.al (2015) conducted a study to find how ongoing migration in different parts of India and how it is crucial towards the improving livelihood. The construction industry is important for Indians migrate rural to urban area. Setting a unique example of Public Private Partnership, the Department of
Community Medicine collaborated with a construction company in Vidyavihar (West), Mumbai, employing a large number of migrant workers, to provide comprehensive health services during the working hours of the hospital over $90 \%$ of urban construction workers are rural migrants, and majority of them work in construction. The author's review of the literature regards the work related risks, also analyses the risks embedded in their work and social status. In depth interviews of 20 persons with construction workers, carried out to demonstrate the risks. The results suggest that rural construction workers in cities were exposed to problems such as not being paid for their work in time, their miserable living conditions, to pay their own healthcare by them and no savings in the old age. This paper also highlights the problems of policy implementation that failed to recognize the complexity faced by these workers.

A study was conducted by Anu Rail et.al (2012) on construction sector; it has the largest number of unorganized labourers after agricultural sector in India, a sample of 100 women construction workers were selected in Kolkata, West Bengal. Almost half the workforce is unskilled women without any professional elevations. Their multifaceted problems related to work, viz., lack of continuity, insecurity, wage discrimination, gender and sexual harassment, unhealthy job relationship, lower wages, and poor job satisfaction. However this construction industry overwhelmingly attracts female workers due to their poverty, also the single and the derelict / destitute women with children to support the family. Their partners mostly are often drunkards or found to have other sexual partners and find themselves in debt trap. Unlike the women, men who usually come as small boys to assist the masons as helpers and finally, graduate as masons, some of them later become contractors and move up the social ladder. Hence the female labourers require empowerment through training and skill development. This study also helps to identify the issues related to working environment of these poor and most vulnerable segments of the Indian society.

Aruna Solanki et.al (2014) conducted a study by the differences in wage rates due to the location of working place, hours of work, working conditions, type of manufactured product and other factors. In Indian labor market, the earning and wages are considerably raised but the problem of wage 
differentiation is prevailing and it is more in the unorganized sector. The construction sector in India is the second largest economic activity after agriculture as well as in providing employment opportunity. The present study is focused on the issues of wage differentiation in the similar construction area at a different working site in Surat city. We have selected 200 migrant unskilled construction workers by stratified random sampling technique from unorganized and organized sectors. It's revealed that there is wage differentiation exists between the male and the female workers, Naka and Non-Naka workers and also in the organized and the unorganized construction sectors.

Tikoo et.al, (2013) conducted a study on the Construction work of women in un-organised sector in India about high risk such as heavy overhead load, operation of heavy machinery, handling of muddy materials, high rise working in extreme temperature as well as noisy condition. Though they contribute a lot to our economic growth, simultaneously they are undergoing various exploitation. This study was undertaken to assess the suitability of work place environment, work hazard and their occupational health problems. The study was carried out in four districts (Gurgaon, Faridabad, Ambala and Panipat) of Haryana and total sample of 600 women selected (150 from each district). The results revealed that almost all the women construction workers experienced exposure to gases, direct sun rays, animal assaults, soil fungus, extreme weather, electric arc welding and they faced multi health hazard due to inappropriate environmental parameters. The study disclosed that there should be effective implementation of health and safety management at work place.

\section{Methods}

The researcher adopted descriptive design for this study. In this study the researcher adopted the purposive sampling method to select sample of 63 women construction workers. The researcher has collected data by using semi structured interview schedule.

Table - 1: Socio - Economic Status of women construction workers (N-63) Socio-Economic Conditions of women construction workers

\begin{tabular}{|l|l|l|l|}
\hline SL. No & Variables & No of Respondents & Percentage \\
\hline $\mathbf{1 .}$ & Age & 6 hend & \\
\hline & $20-24$ & 6 & 9.5 \\
\hline & $25-29$ & 5 ment & 7.9 \\
\hline & $30-34$ & 8 & 12.7 \\
\hline & $35-39$ & 14 & 22.2 \\
\hline & $40-44$ & 7 & 11.1 \\
\hline & $45-49$ & 13 & 20.6 \\
\hline & Above 50 & 10 & 15.9 \\
\hline $\mathbf{2 .}$ & Religion & & \\
\hline & Hindu & 51 & 81.0 \\
\hline & Islam & 3 & 4.8 \\
\hline & Christian & 9 & 14.3 \\
\hline $\mathbf{3 .}$ & Native place & & \\
\hline & Rural & 57 & 90.5 \\
\hline & Urban & 6 & 9.5 \\
\hline $\mathbf{4 .}$ & Marital status & & \\
\hline & Married & 50 & 79.4 \\
\hline & Widow & 13 & 20.6 \\
\hline $\mathbf{5}$ & Income & & \\
\hline & $5000-6000$ & 33 & 52.4 \\
\hline & $6001-7000$ & 22 & 34.9 \\
\hline & $7001-8000$ & 8 & 12.7 \\
\hline $\mathbf{6}$ & Community & & \\
\hline & BC & 43 & 68.3 \\
\hline & MBC & 12 & 19.0 \\
\hline & & & \\
\hline
\end{tabular}


International Journal of Trend in Scientific Research and Development (IJTSRD) ISSN: 2456-6470

\begin{tabular}{|l|l|l|l|}
\hline & SC & 8 & 12.7 \\
\hline $\mathbf{7}$ & Type of Family & & \\
\hline & Joint family & 19 & 30.2 \\
\hline & Nuclear Family & 44 & 69.8 \\
\hline
\end{tabular}

In the current study of the concentration of the women workers in the age group of above 35 to 39 years. Majority of respondent are from the Hindu women workers (81\%) (Muslim 4.8\%) (Christian 14.3\%) In the study $79.4 \%$ percent of women workers were married. $20.6 \%$ of are widows. It is noted that working area, rural $90.5 \%$ and urban $9.5 \%$ and 33 of them having family income of Rs.5,000 to 6,000/(52.4\%),Rs. 6000to 7000/- (34.9\%) and above 8000 $(12.7 \%)$, With regard to the types of the family, most of the respondents are living in nuclear family $(69.8 \%)$ and $(30.2 \%)$ are joint families.

Working conditions of women construction workers

Working conditions of women construction workers

\begin{tabular}{|c|c|c|c|}
\hline SL. No & Variables & No of Respondents & Percentage \\
\hline \multirow[t]{3}{*}{1.} & Risk to life & & \\
\hline & 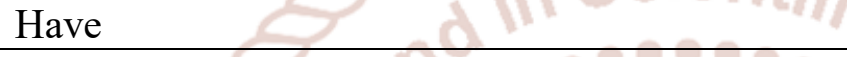 & 14 & 22.2 \\
\hline & Have Not & 49 & 77.8 \\
\hline \multirow[t]{3}{*}{2} & Abuse at the work place & 0 & \\
\hline & Faced $\rightarrow \&$ & 210 & 33.3 \\
\hline & Not Faced $\quad \mid \cup\|\cup\|$ & 42 & 66.7 \\
\hline \multirow[t]{3}{*}{3} & Distance to workplace & 2 & \\
\hline & 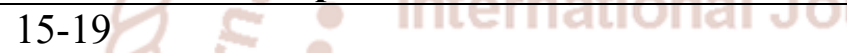 & 23 & 36.5 \\
\hline & of Trend in Scie & 40 & 63.5 \\
\hline \multirow[t]{4}{*}{4.} & $25-30>0$ & 0 & 0 \\
\hline & Access to clean drinking water search all & 0 & \\
\hline & 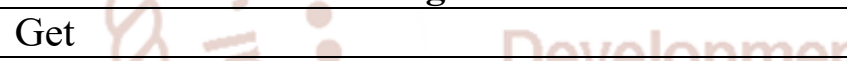 & 0 & 33.3 \\
\hline & Not Get & 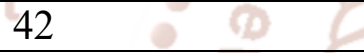 & 66.7 \\
\hline \multirow[t]{3}{*}{5.} & Toilet facilities at workplace & . & \\
\hline & Have Y ISSIN: $2450=041$ & 5 & 7.9 \\
\hline & Have Not & 58 & 92.1 \\
\hline \multirow[t]{3}{*}{6.} & Relationship with friends \& co-workers & & \\
\hline & Have & 14 & 22.2 \\
\hline & Whan 2 & $49 \bigcirc$ & 77.8 \\
\hline \multirow[t]{3}{*}{7.} & Appreciation of work by supervisor & 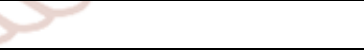 & \\
\hline & Appreciated & 58 & 92.1 \\
\hline & Not Appreciated & 5 & 7.9 \\
\hline \multirow[t]{3}{*}{8.} & praise co- worker for the work they do & & \\
\hline & Yes & 44 & 30.2 \\
\hline & No & 19 & 69.8 \\
\hline \multirow[t]{3}{*}{9.} & $\begin{array}{l}\text { Sharing personal problems/issues with co- } \\
\text { workers }\end{array}$ & & \\
\hline & Share & 55 & 87.3 \\
\hline & Not Share & 8 & 12.7 \\
\hline \multirow[t]{3}{*}{10.} & Sharing of food with others in the work place & & \\
\hline & Share & 2 & 3.2 \\
\hline & Not Share & 61 & 96.8 \\
\hline
\end{tabular}


In the current study of the working condition of women construction workers in the age group of above 35 to 39 years have indicated their day to day conditions at work pace. Majority of respondent $(77.8 \%)$ said no risk to their life at work place and $22.8 \%$ are opposite to that version. Facing abuse at work place $66.7 \%$ said No but $33.3 \%$ had faced abuse at work place. They said distance to the work place is minimum from $15 \mathrm{KM}$ to maximum $24 \mathrm{KM}$. Regarding clean drinking water availability at work place, majority said (66.7\%) not available but 33.3\% are opposite to that. Toilet facility at work place, majority of them (92.1\%) said not available and struggle for natural call, whereas $07.9 \%$ says facility of toilet is available. They $(77.8 \%)$ had said no good relation with friends \& co-workers but $22.2 \%$ was contradictory. Work appreciation by supervisor was yes from $92.1 \%$ and $7.9 \%$ was No to the same. Regarding praising of co-worker at the work they perform. Sharing of personnel problem/issues with co-workers $87.3 \%$ affirmative and 12.7 was No. Food sharing with others at work place, majority $(96.8 \%)$ said no and meagre $(3.2 \%) \%$ said yes.

Table - 3

Affected the problem of working women construction workers

\begin{tabular}{|l|l|l|l|}
\hline S.No & $\begin{array}{l}\text { Problem of } \\
\text { working women }\end{array}$ & Frequency & Percentage \\
\hline \multirow{1}{*}{} & $\begin{array}{l}\text { Urinary tract } \\
\text { Infection }\end{array}$ & & \\
\cline { 2 - 4 } & Have & 50 & 79.36 \\
\cline { 2 - 4 } & Have Not & 13 & 20.64 \\
\hline \multirow{2}{*}{} & $\begin{array}{l}\text { Musculoskeletal } \\
\text { problems }\end{array}$ & & \\
\cline { 2 - 4 } & Have & 42 & 66.66 \\
\hline & Have Not & 21 & 44.34 \\
\hline \multirow{3}{*}{} & $\begin{array}{l}\text { Respiratory/lungs } \\
\text { problem }\end{array}$ & & \\
\cline { 2 - 4 } & Have & 36 & 57.14 \\
\cline { 2 - 4 } & Have Not & 27 & 43.86 \\
\hline \multirow{4}{*}{} & Dust allergy & & 92.1 \\
\cline { 2 - 4 } & Have & 56 & 7.9 \\
\cline { 2 - 4 } & Have Not & 05 & 85.13 \\
\hline \multirow{5}{*}{} & Skin Disease & & \\
\cline { 2 - 4 } & Have & 10 & \\
\cline { 2 - 4 } & Have Not & 53 & \\
\hline
\end{tabular}

The data shows that the women construction workers affected by numerous health issues on which 8 of 10 have a urinary tract infection and $66.66 \%$ them suffer from musculoskeletal problems. The lungs related ailments are faced by $57.14 \%$ respondents and $92.1 \%$ women workers have a allergic to dust. However, the 9 out of 10 women not having any skin disease.

\section{CONCLUSION}

The constitution of India provides equal rights and opportunities to both the genders. Construction sector falls under unorganized sector of an economy. The problems of women construction worker in the workplace are one of the major issues in the contemporary social problems. Majority of the women construction workers are facing lots of difficulties like absence of social security, low wages, sexual harassment, gender discrimination, etc Main things ignorance and illiteracy, small and scattered size of establishment. They are working under unsecured environment or work culture. The main problems faced by them are the lack of security; there is $50 \%$ no security for their life in the working site. Some other problems faced by the financial problems. There are many health hazards, musculoskeletal disorders, Workplace intervention measures aimed at occupational physical tasks and activities seem justified for both occupations.

\section{REFERENCES:}

1. Adinarayana Reddy P, Syam Mohan David Raju B, Satyavathi R.B (2011), "Women and Work Participation Status and Training Opportunities", Sonali Publications, New Delhi, PP.20-40.

2. "Baghere J (2005) (ed.), "The changing status of women in west Bengal", 19700-2000, the challenge Ahead, sage publications India Pvt. Ltd., New Delhi, PP-113.

3. Dr. K.A. Rajanna (2015) Socio-economic Status of Women Workers in Construction Industry: a Case Study. Chikmagalur District of Karnataka. IJMSS Vol.03 Issue-03, (March,2015) ISSN: 2321-1784 International Journal in Management and Social Science (Impact Factor- 3.25).

4. T.Subramani, et.al (May 2015) Analysis of Construction Workers Migrate from Industries International Journal of Application or Innovation in Engineering \& Management (IJAIEM). Web Site: www.ijaiem.org Email: editor@ijaiem.org Volume 4, Issue 5, May 2015.

5. Anu Rai1, et.al (2012) Workplace Culture \& Status of Women Construction Labourers:A case study in Kolkata, West Bengal. Indian Journal of Spatial Science Vol - 3.0 No. 2 Winter Issue 2012 pp44 - 54 
6. Aruna Solanki et.al (2014) DISCRIMINATION IN WAGES: A CASE STUDY OF MIGRANT CONSTRUCTION WORKERS IN SURAT CITY. Journal of Economic \& Social Development, Vol. - X, No. 2, December 2014 ISSN 0973 - 886X.

7. S.Tikoo et.al, (2013) Work Place Environmental Parameters and Occupational Health Problems in Women Construction Workers in India. Global Journal of Management and Business Studies. ISSN 2248-9878 Volume 3, Number 10 (2013), pp. 1119-1128 (C) Research India Publications http://www.ripublication.com/gjmbs.htm.

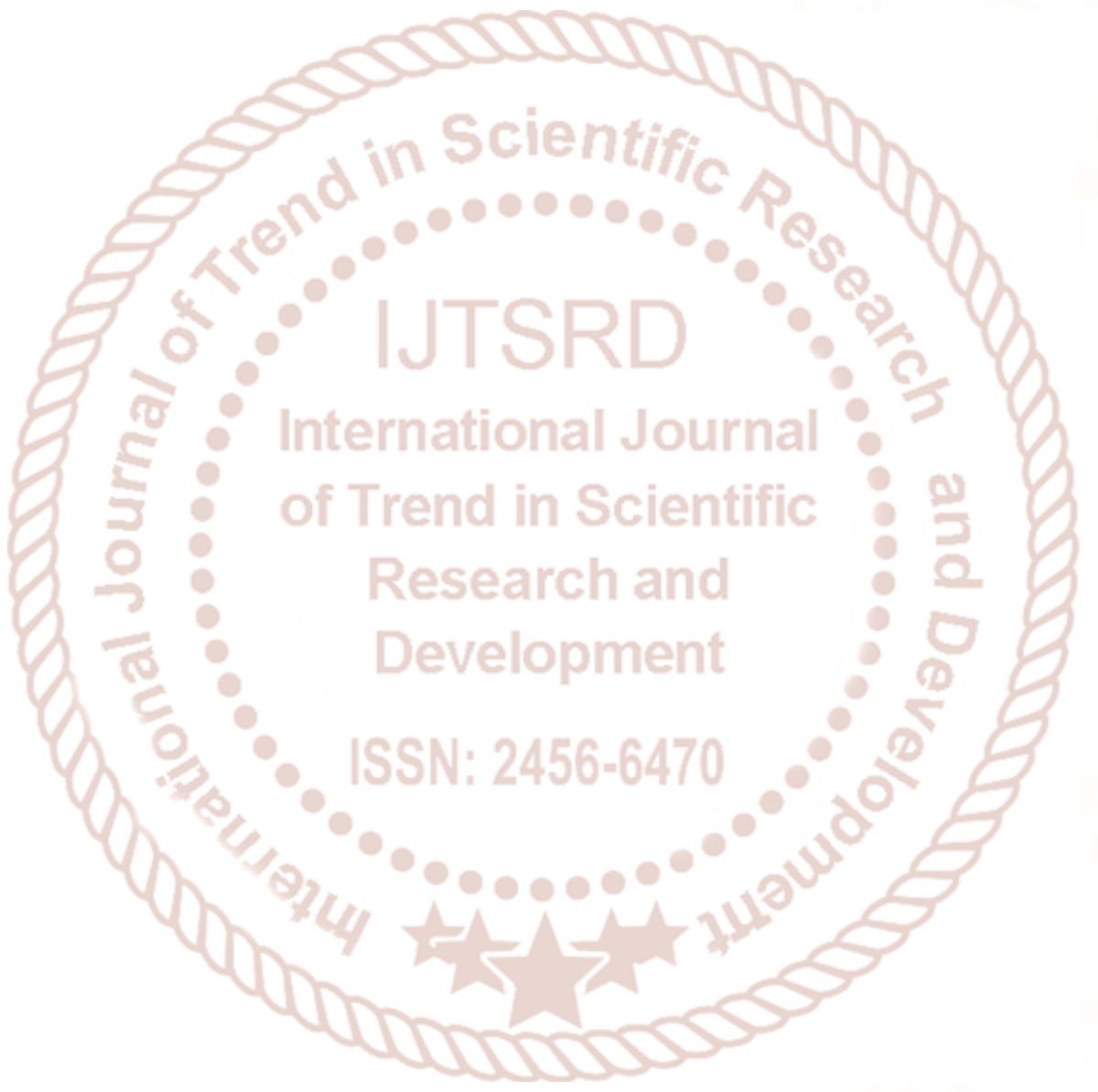

